\title{
Ki nyeri el az aranyszőrü bárányt? avagy nyugat-afrikai migrációs életutak egy folyamatosan változó Európában ${ }^{1}$
}

\author{
JÁNOSY ORSOLYA ${ }^{2}$
}

Apostolos Andrikopoulos disszertációjának már a címe is irodalmi igényességet sugall: „Nyugat-Afrika argonautái” (Andrikopoulos 2017). A görög mitológiában Argó hajósai, a legjobb ötven görög harcos, Iaszón vezetésével elindul Iolkhiszból a kis-ázsiai Kolkhiszba, hogy ott megszerezze a Poszeidon és Theophané nászából született aranyszőrű kos lenyúzott bőrét, a várost védő aranygyapjút, amely hazájában trónra segítheti Iaszónt. A kalandos út során a harcosoknak számos próbát kell kiállniuk, veszélyes akadályt leküzdeniük, hogy életüket is kockáztatva végül eljussanak Kolkhiszba, ahol egy leküzdhetetlennek tűnő hatalmas sárkány őrzi az aranygyapjút. Végül, ahogyan az a mesékben lenni szokott, a kolkhiszi király szépséges és okos leánya Médeia beleszeret Iaszónba, varázstudományával elaltatja a sárkányt, így segítve győzelemre, és hazájában később trónra szerelmét (Szabó 1998).

Andrikopoulos nyugat-afrikai argonautái is keresik a maguk „aranyszőrű bárányát”, azaz a boldogulást. Legfóbb motivációjuk, hogy vinni szeretnék valamire az életben, tisztességgel helyt akarnak állni és eltartani önmagukat és gyakran népes családjukat. A sors iróniája, hogy helytállásuk legtöbb esetben csak sajátos módszerekkel, az európai törvények kijátszásával, vagy megkerülésével lehetséges. Mint a jó regények esetében általában, az író pontosan láttatja főhősei motivációit, így az olvasó átérezheti helyzetüket, dilemmáikat, kudarcaikat, már-már azonosulhat a szereplőkkel és nagyon szorít a boldogulásukért. Talán pont ezen erényeiért nyerte el a mű 2018-ban a migráció, integráció és társadalmi kohézió területén folytatott kutatások legjobb disszertációnak járó Maria Ioannis Baganha-díjat.

A kutatás bemutatja, hogy a bizonytalan jogi státuszú, illetve jogszerütlenül Hollandiában tartózkodó nyugat-afrikai, főként ghánai és nigériai bevándorlók hogyan építik ki, és használják rokoni, ismerősi, avagy „sorstársi” kapcsolatrendszerüket,

${ }^{1}$ Andrikopoulos, A. (2017): Argonouts of West Africa: Migration, Citizenship and Kinship Dynamics in a Changing Europe. Doktori (PhD-) értekezés, Amsterdam, University of Amsterdam https://dare.uva. $\mathrm{nl} /$ search?identifier $=030 \mathrm{~d} 3583-4 \mathrm{c} 19-43 \mathrm{e} 4-8 \mathrm{ace}-67327920138 \mathrm{~d}$

${ }^{2}$ Doktorandusz, Debreceni Egyetem Humán Tudományok Doktori Iskola Szociológia és Társadalompolitika Doktori Program. 


\section{OLVASS FELESLEGESET!}

hogy személyazonosító okmányokra, útlevélre, vízumra, munkavállalási és tartózkodási engedélyre tegyenek szert és ezek birtokában hosszú távon munkát vállaljanak. A kutatás célja, hogy az interjúalanyok életútján keresztül megértsük az egymást kölcsönösen támogató „rokoni viszonyok rendszerét”, azaz a tradicionális társadalmakban fellelhető, az élet minden területét átszövő kapcsolati háló múködését, a kölcsön-identitás, azaz a más nevén, más dokumentumaival való munkavállalás szerepét, az ezért kapott részesedés, az „abusa” jogát, és az érdek-, illetve kevert-státuszú házasságok működését. Megérthetjük, hogy ezen rokoni kapcsolati háló müködése az elmúlt közel 20 évben miként alkalmazkodott a változó, egyre szigorodó európai jogi szabályozásokhoz, bevándorlási és munkavállalási törvényekhez, a bővülő Európai Unió által teremtett új lehetőségekhez. Feltételezhetnénk, hogy a modern, egyenjogúságra törekvő társadalmakban a rokoni szálak szerepe háttérbe szorul, de mint a tanulmány bizonyítja, ezen kapcsolati hálók működése a modern társadalom bevándorló- közösségeiben felerősödik, egymás kölcsönös segítése a túlélési-stratégiájuk elengedhetetlen feltételévé válik. Mint ahogyan Carsten rámutat, a rokoni kapcsolatok szerepe nem halványul el, csak folyamatosan a helyzetnek megfelelően változik, átalakul (Carsten 2004).

Mit is értünk jelen esetben rokoni kapcsolatok alatt? Nem feltétlenül szoros, vérségi kapcsolatot. A tanulmányból kiderül, hogy a nyugat-afrikai bevándorlók számára, mint a tradicionális társadalmakban, a rokonság fogalma, a mi modern, európai értelmezésünkhöz képest jóval tágabb, egyfajta testvériséget, atyafiságot, földiséget, sorsközösséget és akár kölcsönös, egymást segítő érdekszövetséget jelent. A vérségi rokonságon túl testvérként tekintenek az ugyanazon közösségből, városból, régióból származó társukra, vagy a gyülekezeti fivérükre, vagy egy barátra, akivel kölcsönösen támogatják egymást.

A marginális helyzetben lévő közösségekben a világ számos pontján megfigyelhető hasonló jellegü, egymást kölcsönösen támogató „rokoni” kapcsolatok rendszere. Carol Stack 1974-ben megjelent tanulmányában (Stack 1974) az amerikai nagyvárosok szegénységben élő afro-amerikai közösségeiben, míg Larissa Lomnitz a mexikói bádogvárosok lakóit vizsgálva jut hasonló megállapításokra (Lomnitz 1977).

A másik vizsgált téma az állampolgári jogok kérdése. A modern társadalmakban az állampolgárság minden állampolgár számára egyenlő jogokat biztosít, ugyanakkor, mint minden tagság, a nem tagokkal, azaz kívülállókkal szemben kirekesztő, és jelentős egyenlőtlenségeket generál. A „migráció korában” (Castles, De Haas, Miller 2014), vagy ahogyan Carling nevezi „az önkéntelen mozgásképtelenség korszakában" (Carling 2002) az állampolgári jogok kirekesztő mechanizmusainak társadalmi kapcsolatokra gyakorolt hatása felerősödik, és a rokoni kapcsolatrendszer müködésében is dinamikus változásokat generál.

A kutatás kvalitatív módszeren, etnográfiai terepmunkán alapszik. Bár a szerző 2007 óta folyamatosan Amsterdamban él és dolgozik, így több szálon kötődik kutatása célcsoportjához, sokukkal baráti kapcsolatokat is ápol, a hivatalos, rögzített 


\section{OLVASS FELESLEGESET!}

adatgyüjtés 2011 októbere és 2012 novembere között az élet három fő helyszínén zajlott: az interjúalanyok lakónegyedében, a többségében nyugat-afrikaiak által lakott Bijlmerben, ahol maga Andrikopoulos is él, munkahelyükön, egy bevándorlókat foglalkoztató gyorsétteremben, ahol a szerző évek óta részmunkaidőben dolgozik, illetve a főként afrikaiak által látogatott Pünkösdi gyülekezetben, ahová bibliaolvasó órára jár és önkéntes feladatokat végez. Bijlmer, Amsterdam főként bevándorlók által lakott negyede, ahol az Amsterdamban regisztrált ghánaiak 72\%-a és a nigériaiak 51\%-a él. A szerző a kutatás során összesen 36 személlyel rögzített 63 interjút, ezen felül még jelentős számú beszélgetést folytatott, főként jogszerűtlenül Amszterdamban élő bevándorlókkal, melyek a téma bizalmas jellege miatt, nem kerülhettek rögzítésre. Az interjúk angolul folytak, amely Ghánában és Nigériában is a hivatalos nyelv, valamint az Amsterdamban élő nyugat-afrikai közösség közös nyelve is.

Andrikopoulos a kutatás során együtt él interjúalanyaival, a Bijlmerben bérelt lakáson három nigériai férfival osztozik, közösen járnak bevásárolni, szórakozni, az ő kapcsolatrendszerükön keresztül sok nyugat-afrikai bevándorlóval ismerkedik meg, s a közösség tagjává válik.

A gyorsétteremben több mint 100 munkavállaló dolgozik, akik közül mindössze kettő holland származású, a többiek észak- és nyugat-afrikai, dél- és kelet- európai, dél-ázsiai, suriname-i és török bevándorlók. Kollégáinak 30\%-a tartozik a kutatás célcsoportjához, vagy nyugat-afrikai származása miatt, vagy nyugat-afrikai párja révén.

A kutatás harmadik helyszíne a Pünkösdi Egyház gyülekezete. A pünkösdizmus egyre nagyobb népszerűségnek örvend Nyugat-Afrikában, valamint az afrikai diaszpórákban. A gyülekezet már nem pusztán csak a vallás gyakorlásának helyszíne, hanem a társas kapcsolatoké is, ahová a hívők ismerkedni, beszélgetni, kikapcsolódni járnak. Fontos hangsúlyozni, hogy a kutatás során a szerző a közösség teljes jogú tagjává válik, a közösség tagjaival személyes kapcsolatokat alakít ki, amely megalapozza az ilyen érzékeny témát érintő interjúkhoz elengedhetetlen bizalmi légkör kialakulását. Amint az interjúknak a közösség belső csatornáin keresztül híre megy, egyre többen szeretnének részt venni a kutatásban, elmesélni személyes tapasztalataikat, utazásuk történetét, talán még egy kicsit büszkélkedni is az elért eredményeikkel.

A kutatás elsődleges célcsoportját tehát az Amsterdamban élő nyugat-afrikai, fóként ghánai és nigériai bevándorlók alkotják, másodlagos célcsoportként azonban megjelennek a nyugat-afrikaiakkal szoros kapcsolatot fenntartó és együttmüködő bevándorlók csoportjai, pl. a korábbi holland gyarmatokról, a Karib-térségből, Surinameból, vagy Curacaoból származó afrikai leszármazottak csoportja, valamint kisebb vizsgálati csoportként a kelet-európaiak és fehér-bőrű hollandok is.

A hivatalos statisztikák alapján 2012-ben 11463 ghánai és 1712 nigériai bevándorló élt Amsterdamban, a jogszerútlenül ott tartózkodó, vagy bizonytalan jogi státuszú bevándorlók számáról nincs hivatalos adat, számukról a szerző sem bo- 


\section{OLVASS FELESLEGESET!}

csátkozik becslésekbe. Bizonytalan jogi státuszú bevándorlók alatt a szerző azokat érti, akik ugyan rendelkeznek saját dokumentumokkal és ideiglenes tartózkodási engedéllyel, de a hosszútávú tartózkodásuk bizonytalan, mivel tartózkodási engedélyük maximum 6 hónapig érvényes, míg a jogszerűtlenül az országban tartózkodók nem is rendelkeznek saját dokumentumokkal, Hollandiába hamis úti okmányokkal utaztak be. Paradox módon az ideiglenes tartózkodási engedéllyel rendelkező bevándorlók sok esetben jóval kiszolgáltatottabbnak érzik helyzetüket a jogszerűtlenül az országban tartózkodókhoz viszonyítva, hiszen ők bár 6 hónapig legálisan, de a hatóságok látókörében élnek, és ha nem sikerül meghosszabbítani a tartózkodási engedélyüket, el kell hagyniuk az országot. Ezzel szemben a dokumentumokkal nem rendelkező társaik éveken át egy hozzájuk külsőleg hasonló, legálisan az országban tartózkodó „rokon” neve alatt vállalnak munkát és nem feltétlenül jutnak a hatóságok tudomására.

A tanulmány középső három fejezete az interjúalanyok történetei révén három téma köré rendeződik, amelyek az Európába történő viszontagságos utazás, a kölcsön-identitások rendszerének a bemutatása, illetve a különböző területről érkező bevándorlók közötti házasságok története.

Jason történetén keresztül könnyen megérthetjük, miért is nevezi a szerző főhőseit „argonautáknak”. Jason 1970-ben született egy dél-ghánai kis faluban. Földműves apjának három feleségétől 22 gyermeke volt, a család nincstelenül, mély szegénységben élt. Jasont a legjobban az viselte meg, hogy a közösség a nincstelensége miatt megbélyegezte. Egyetlen célja az volt, hogy kitörjön reménytelen helyzetéből, váljon „valakivé” és tisztességesen eltartsa családját, támogassa rokonait, helytálljon az életben.

A 90-es évek elején elkezdett spórolni, úgy tervezte, hogy Angliában vállal munkát. Az évek során megtakarított pénze azonban nem volt elég ahhoz, hogy hivatalos okmányokkal Európába utazzon. Közben barátnője teherbe esett, így utazása sürgetővé vált, ezért úgy döntött, hogy mint ismerősei közül már sokan, ő is hamis papírokkal, vagy mások eredeti dokumentumait felhasználva próbál szerencsét.

Először Dél-Afrikába szeretett volna utazni, de oda saját útlevelével nem kapott vízumot, ezért először Zimbabwe-ba repült, ahová nem volt szüksége vízumra. Életében először hagyta el az országot. A repülőjegy árát saját megtakarításaiból és ismerőseitől kapott kölcsönből fedezte. Érkezéskor azonban a határőr nem akarta beléptetni, úgy vélte, hogy a Ghánában hivatalosan igényelt útlevele hamis. Hosszú vita és 50 \$ kenőpénz kifizetése után végül engedték beutazni az országba. Harareban 200 \$-ért vásárolt egy lopott malawi útlevelet, ezzel próbált több ghánai társával együtt átjutni a dél-afrikai határon, ahol az elektronikus határellenőrzési rendszer miatt nagy volt a lebukás kockázata, ezért inkább a zöld-határon át történő bejutás mellett döntöttek. Dél-Afrikában libériai menekültnek vallotta magát, így menekültstátuszhoz jutott és 6 hónapig álnéven utcai árusként dolgozott. Egy újabb malawi útlevél megvásárlása után, vett egy londoni repülőjegyet, de már a gépre sem jutott 


\section{OLVASS FELESLEGESET!}

fel. A kudarc után új stratégiát kellett kidolgoznia. Most észak-ghánai menekültnek vallotta magát, így újabb 6 hónapig maradhatott Dél-Afrikában, vett egy zimbabwei útlevelet, amellyel Kanadába készült beutazni. Hasonló helyzetben lévő társaitól úgy hallotta, hogy a Kanadába történő bejutás Ázsiából zökkenőmentesebb, ezért először Malajziába repült, de ott már nem tudott felszállni a torontói járatra. Malajziában 7 hónapon át egy ott élő nigériai ismerőse munkavállalási engedélyével egy építkezésen dolgozott, bankszámlát nyitott és már elég jól keresett ahhoz, hogy családját és közben megszületett gyermekét is támogatni tudja. Zimbabwei útlevelével többször utazott Thaiföldre, útlevelébe pecséteket gyüjtött, hogy az hitelesebbnek tűnjön, végül Tajvanon keresztül készült Kanadába utazni. A tajpeji repülőtéren nehézségek árán ugyan, de már beszállt a Vancouverbe induló járatra, de pár perccel a felszállás előtt a határőrök őrizetbe vették feltételezhetően hamis útlevele miatt. Nem volt más választása csak visszatérni Dél-Afrikába, ahol okirathamisításért 6 hónapra elítélték. Szabadulása után két évig egy hotelben dolgozott recepciósként Johannesburgban. Miután elég pénzt gyưjtött újra össze, egy dél-afrikai ismerőse nevén, aki már rég elhagyta az országot, csináltatott magának eredeti személyigazolványt, majd biometrikus útlevelet. Így már rendelkezett hiteles útiokmányokkal, és a bankszámláján elegendő összeggel, de a dél-afrikai nyelvjárások ismerete nélkül nagyon könnyen lebukhatott volna Dél-Afrikában, ezért úgy döntött, hogy Tanzániából repül Európába, Tanzániába pedig Szváziföldön, Mozambikon és Malawin keresztül buszon jutott el. 5 év 4 hónapnyi viszontagságok után 8 név használatával és 11 országon keresztül végre megérkezett Amsterdamba, ahonnan Londonba ment volna tovább, de mivel nem rendelkezett elegendő pénzzel a Nagy-Britanniába történő belépéshez, a határról visszafordították. Egy Dél-Afrikában megismert ghánai lakótársán keresztül jutott vissza Amsterdamba, ahol egy Bijlmerben élő ismerős papírjaival egy építkezésen talált munkát, majd később másik két ismerős papírjait is igénybe véve, további két munkahelyen dolgozott egyszerre. Az amsterdami évek alatt 3 használt autót vásárolt, melyeket hazaküldött Ghánába, támogatta a családját és megtakarított 9000 \$-t. 2005-ben egy munkaügyi ellenőrzés során az építkezésen elkapták, s a hatóságok elindították volna a kitoloncolását, de mivel nem rendelkezett saját dokumentumokkal, paradox módon ezt sem tudták egyszerúen kezdeményezni. Jason végül saját elhatározásából úgy döntött, hogy együttműködik a hatóságokkal és hazatér családjához. Míg az odaútja közel 5 évig tartott, a visszaútját 7 óra alatt teljesítette.

Ghánában a megtakarított pénzéből és a hazaküldött autókból elindított egy kis használt-autó kereskedést, mely az évek során sikeres vállalkozássá nőtte ki magát, feleségül vette mennyasszonyát és további 4 gyermekük született, folyamatosan segíti rokonait, barátait. Accrában egy 6 hálószobás házat épített családjának, s jelenleg unokaöccse orvosi tanulmányait finanszírozza. A közösség felnéz rá, s ő büszke lehet magára, mert beteljesítette az álmát, s vitte valamire az életben és most már saját nevét és dokumentumait használva akkor utazik Európába, amikor csak kedve tartja. 


\section{OLVASS FELESLEGESET!}

A kölcsön-identitás, illetve az ebből származó jutalékok rendszerét talán Afua történetén keresztül érthetjük meg legjobban. Afua, a nigériai származású takarítónő 1997-ben férjét követve érkezett Amsterdamba. Kezdetben egy a gyülekezetben megismert ghánai nő, Barbara papírjaival vállalt munkát egy takarítócégnél. Abban állapodtak meg, hogy Barbara leveszi a keresete 25\%-át, mint „abusat” és a fennmaradó 75\%-ot minden hónapban személyesen odaadja Afuának. Az abusa a dokumentumok használatáért a tulajdonosnak járó jutalékot jelenti, mely általában a jövedelem 30\%-át teszi ki, de bizonyos esetekben elérheti az 50\%-ot is. A dokumentumok használatával a papírokkal nem rendelkező bevándorló keresethez jut, míg a tulajdonos duplán jól jár, hiszen nem csak a jutalékot kapja meg, de számos más előnyt is élvez, bevallott jövedelme alapján pl. magasabb nyugdíjra is számíthat. Barbara és Afua megállapodása révén tehát mindketten jól jártak, úgy érezték, hogy kölcsönösen segítik, támogatják egymást, egymás nővérei lettek és együttműködésük Afua tartózkodásának legalizálásáig, azaz 8 évig jól működött. Afua közben már magánházaknál is elkezdett feketén, saját nevén is takarítást vállalni, majd megkereste egy újabb gyülekezeti testvére, hogy dolgozhatna esténként a húga, Miriam papírjaival is egy ételcsomagoló üzemben. Afua hajnalban tehát Barbara néven cégeknél takarított, napközben saját nevén magánházakhoz járt, míg esténként Miriamként szendvicseket csomagolt. Miriammal azonban már nem tudott olyan szoros kapcsolatot kialakítani, mint Barbarával, és a kapcsolatuk végét jelentette, amikor a gyülekezetben azt kezdték pletykálni Miriamról, hogy prostituált. Afua nem volt képes Miriam néven tovább dolgozni, hívőként elátkozottnak érezte magát attól, hogy azonosulni kényszerül egy prostituálttal. Az identitás-kölcsön nem csupán üzleti viszony tehát, sokkal több annál, egyfajta testvériség, amelyben mindkét fél egymás életének részévé válik, kölcsönös függőségi viszonyba kerül. Amikor 8 évvel később Afua megszerzi saját munkavállalási engedélyét, első dolga, hogy ingyen kölcsönadja azt a gyülekezetbe frissen érkezett nigériai lánynak, hogy segítse a beilleszkedését.

A harmadik vizsgált témakör a transznacionális házasságok szerepe. Az interjúkból kirajzolódik, hogy az Európai Unió bővülése, hogyan hatott a nyugat-afrikai bevándorlók párválasztására is.

Ahogy az James és Afua történetéből is látszik a '90-es években a nyugat-afrikai bevándorlók főként saját afrikai közösségüktől számíthattak támogatásra. Érdekes módon az afrikai közösség tagjainak számítottak a Karib-térségből, pl. Surinameból érkező afrikai származású bevándorlók is. Suriname, korábbi nevén Holland Guyana, 1975-ben vált függetlené Hollandiától, az ország hivatalos nyelve jelenleg is a holland, állampolgárai jogosultak voltak a holland állampolgárságra, a Hollandiában történő letelepedésre. Az Amsterdamba érkező suriname-i bevándorlóik is fóként Bijlmerben telepedtek le.

A történelem során, a 18. és 19. században a kávé, kakaó, és cukornád termelés miatt, a holland ültetvényesek nagy számú, főként a mai Ghána területéről származó rabszolgát hurcoltak be suriname-i gyarmataikra és dolgoztattak birtokaikon. 


\section{OLVASS FELESLEGESET!}

Leszármazottjaik megjelenésükben továbbra is hordozták afrikai származásukat, és 1975 után könnyen megszerezhették a holland állampolgárságot, így a '90-es években Hollandiába érkező nyugat-afrikaiak, hasonló megjelenésük miatt, könynyen dolgozhattak az ő nevük alatt. Sokukban Bijlmerbe érkezve erősödött meg az afrikai-identitástudat, egyfajta nosztalgia az afrikai múlt iránt és szívesen jártak az afrikai közösségekbe, vallási gyülekezetekbe is.

Judith, a suriname-i származású Hollandiában nevelkedett nő, identitásválsága során kerül a Pünkösdi gyülekezetbe, ahol otthon érzi magát. A ghánai származású lelkész közvetítésével megismerkedik Jack-kel, a papírokkal nem rendelkező ghánai bevándorlóval, akivel pár hónapos ismeretség után összeházasodnak, hogy legalizálják Jack hollandiai tartózkodását. Jack és Judith házassága azóta is müködik, két gyermekük született, és jelenleg azt tervezik, hogy Ghánába költöznek és ott indítanak el egy kisvállalkozást.

A karibi származású Kelly sorsa már nem alakult ilyen szerencsésen. Kisgyermek korában fogadta örökbe egy fehér holland család és egyetlen feketeként nevelkedett egy teljesen fehér közösségben. Első, suriname-i férjével kötött házassága hamar zátonyra fut, férje gyakran bántalmazza és prostitúcióra is kényszeríti, kapcsolatukból két gyermekük is születik. Válásuk után Kelly nem találja a helyét, kívülállónak érzi magát hazájában, Hollandiában. A Pünkösdi gyülekezetben talál megértő, befogadó közösségre, mely kialakítja és erősíti benne afrikai-identitását. Ebben az érzelmileg labilis helyzetben a Facebookon keresztül megismerkedik és beleszeret Sambe, egy Accrában élő ghánai férfiba. Sam kedves üzenetekkel halmozza el, gondoskodónak tűnik és minden vágya, hogy személyesen is megismerhesse Kelly-t. Kelly minden pénzét felhasználva Ghánába utazik, hogy összeházasodhasson Sammel és Hollandiában éljenek tovább. Két boldogságban eltöltött hét után egyszer megnézi Sam telefonját és rádöbben, hogy szerelme összesen 435 nővel vált szerelmes üzeneteket a világ számos pontján. Kapcsolatuk pár további hónap vajúdás után megszakad.

Az Európai Unió 2004-es és 2007-es bővítésével, a volt szocialista országok belépésével új trendek alakulnak ki a nyugat-afrikaiak párválasztásban. 1996 - 2000 között a nigériaiak 67\%-a, míg a ghánaiak 26\%-a holland, suriname-i vagy Karib-térségből származó párral kötött házasságot, ez az arány 2011-2015 között már 31\%-ra esett vissza a nigériaiak, és 13\%-ra a ghánaiak körében. Ezen időszakokban a „nyugatiakkal" kötött házasságok 13\%-ról 36\%-ra változtak a nigériaiak, míg 3\%-ról 9\%-ra a ghánaiak körében. Ezen besorolás szerint Görögország, Spanyolország, Közép- és Kelet-Európa is nyugatinak számít. A 2004-es törvényi szabályozás, a szabad mozgás és letelepedés joga ugyanis megkönnyítette az Európai Unió állampolgárainak 3. országból származó házastársai számára az Unión belüli mozgást és szabad letelepedést. Valójában egyszerübb volt afrikaiként egy kelet- európai házastárs oldalán Hollandiában letelepedni, mint egy holland állampolgár házastársaként. A beszélgetésekből kiderül, hogy az afrikai férfiak sok esetben túl függetlennek, akaratosnak, problémásnak ítélték meg a demokratikus Európában nevelkedett partnereiket, ér- 


\section{OLVASS FELESLEGESET!}

dekes módon még a suriname-i feleségeket is, akikkel nehezen tudták domináns pozíciójukat kialakítani, azonban az Európa perifériájáról származó nőkkel könnyebb helyzetük volt. Bár szükségük volt európai feleségükre a legális letelepedéshez, feleségeik hasonló szociális-gazdasági státusszal bírtak, mint ők maguk és még hálásak is voltak férjüknek a jól működő nyugat-afrikai kapcsolati hálójukért, amely őket is segítette a munkavállalásban, lakhatásban. A tanulmányban több görög-nigériai és román-nigériai kapcsolatot mutat be a szerző.

A kutatás egyéni életutakon keresztül mutatja be a tradicionális társadalmakra jellemző, de bizonyítottan a modern társadalmak bevándorló közösségeiben is intenzíven múködő, dinamikusan változó rokoni kapcsolatrendszer túlélési-stratégiákban betöltött szerepét. Bár a szerzőnek nem célja az interjúk alapján általánosítani, a kutatásból kirajzolódik egy egységes kép a nyugat-afrikai kapcsolati háló működéséről.

A folyamatosan változó túlélési-stratégiák alkalmazkodó készségét pedig jól szemlélteti a The New York Times cikke (Alderman 2019), amelyből kiderül, hogy a Wolt vagy az Uber Eats regisztrált ételfutárainak már nem éri meg kiszállításonként 3,5 euróért tekerni a biciklit Európa nagyvárosaiban, hanem „alvállalkozóként” alkalmaznak fiatal, jogszerütlenül az országban tartózkodó bevándorlókat, akik a bevétel 50-70\%-ért örömmel elvégzik a munkát helyettük. Franciaországban egy-egy hivatalos futár regisztrációján keresztül egyszerre akár 10-12 fiatal bevándorló is végezheti a kiszállításokat, és teheti ezt a biometrikus adatrögzítés korában.

\section{Irodalom}

Alderman, L. (2019): Food-Delivery Couriers Exploit Desperate Migrants in France. The New York Times, New York, https://www.nytimes.com/2019/06/16/business/uber-eats-deliveroo-glovo-migrants.html (utolsó letöltés: 2019. 10.15.)

Carling, J. (2002): Migration in the Age of Involuntary Immobility. The Theoretical Reflections and Cape Verdean Experiences. Journal of Ethic and Migration Studies 28 (1): 5-42.

Carsten, J. (2004): After Kinship. Cambridge University Press, Cambridge

Castles, S. - De Haas, H. - Miller, M. (2014): The Age of Migration: International Population Movements in the Modern World. Palgrave Macmillan, New York

Lomnitz, L. A. (1977): Networks of Marginality: Life in a Mexican Shanty Town. Academic Press, New York - San Francisco - London

Stack, C. B. (1974): All our Kin: Strategies for Survival in a Black Community. New

York, Harper and Row

Szabó Gy. (1998): Mitológiai kislexikon. Könyvkuckó, Budapest 